\title{
A Study on Body Composition and Hand Grip Strength of Junior Free Style Wrestlers
}

\author{
Parwinder Singh and Ashok Kumar
}

\begin{abstract}
Aim: The aim of this study was to examine the body composition and hand grip strength of different weight categories of junior free style male wrestlers. Method: one hundred fifty $(\mathrm{N}=150)$ male junior free style wrestlers were participated as subjects and they were further divided into five groups according to their weight categories, each group was comprised of thirty wrestlers. Body fat percentage was estimated by using Durnin and Womersley equation and the strength was measured from hand grip test. Results: A statistical significant positive correlation was found between the hand grip strength and age, height, weight, BMI, skinfold thickness and $\% \mathrm{BF}$. Conclusion: it is concluded that the free style wrestling is a weight classified sport; therefore the correlation of weight of the wrestlers with strength is important. The results of the present study also demonstrated the effect of age, height, BMI, and $\mathrm{BF} \%$ on the hand grip strength of wrestlers.
\end{abstract}

Parwinder Singh, Ph.D Student, Department of Sports Science, Punjabi University Patiala (Punjab) India Ashok Kumar, Associate Professor, Department of Sports Science, Punjabi University Patiala (Punjab) India E-mail:akashokin@gmail.com
Key Words: Free Style, Wrestling, Skinfold, Anthropometry, Strength, Fat Percentage

DOI: $10.18376 /$ jesp/2016/v12/i2/111260

\section{Introduction}

A sport of wrestling has a strong tradition that precedes the first Olympic festival in 776 B. C., when Zeus wrestled Kronas for the possession of the earth (Gallagher, 1951). Since then the sport of wrestling continues to grow in popularity because of the discipline and mental toughness it requires to be successful in the sport. Unfortunately, the sport has also been associated with the stigma of "cutting weight" and the practices that accompany the process of competing at designated weight classes. Like the sports of judo, boxing, and competitive weight lifting, wrestling requires its athletes to compete at specific weights or weight classifications. Typically, these weight classifications differ by approximately 7-11 pounds depending on age and style of wrestling. It is common knowledge in present day of wrestling that wrestlers compete in weight classes below their "normal" weight. The purpose of this practice is to gain advantages in strength, speed, and leverage over their opponents (Steen \& Brownell, 1990). The changes in regulation of wrestling have forced several modifications in the fitness requirements of successful wrestlers, which as a result caused an evolution in the training methods (Yoon 2002; Horswill 1992; Sharratt et. al., 1986).Wrestling has been described as an intermittent physical event which produces great strength and muscle power demands of both the upper and lower body (Hubner-Wozniak et. al. 2004; Kraemer et. al. 


\section{Journal of Exercise Science \& Physiotherapy, Vol. 12, No. 2, 2016 ISSN: 0973-2020 (Print) \\ ISSN: 2454-6089 (Online)}

2001; Horswill et. al. 1992 \& 1989; Sharratt et. al. 1986).They generally want to minimize the body fat level and the total body weight without losing their body strength and power (Yoon, 2002). However, no relation was shown between the percentage of fat mass (\%FM) and the level of wrestling success (Yoon, 2002; Horswill 1992). The aim of the present study was to observe the body composition and hand grip strength in different weight categories of junior free style wrestlers. The present investigation was to study the relationship of body composition and hand grip strength in different weight categories of junior free style wrestlers.

\section{Material and Methods}

The study was conducted on 150 male junior free style wrestlers (age between 18-20 years) of five different groups i.e. Group 1- 46-50 kg junior free style wrestlers, Group 2$55 \mathrm{~kg}$ junior free style wrestlers, Group 3- $60 \mathrm{~kg}$ junior free style wrestlers, Group 4 $66 \mathrm{~kg}$ junior free style wrestlers, Group $5-74 \mathrm{~kg}$ junior free style wrestlers. The aim of the study was explained to each participant and signed informed consent was obtained from the participants. The body composition of junior free style wrestlers was estimated as per the method described by Durnin and Womersley (1974). BMI can be categorized according to the WHO (Laquatra, 2004). The handgrip strength of the dominant hands was evaluated using a handgrip dynamometer. The test was performed in the standing position. The subject held the dynamometer in the hand to be tested with the arm at right angles and the elbow by the side of the body. Subject was then asked to squeeze the dynamometer with his maximum isometric effort for a $5 \mathrm{sec}$ period. Test was repeated two times with both hands. The 30 second rest interval was provided between measurements and the highest score was recorded. The results of five groups have been compared with each other. Karl Pearson's coefficient of correlation was used to find the relationship among age, weight, BMI, body composition and handgrip strength variables of free style junior wrestler in five groups according to their weight. To determine the differences between the mean of the various variables among different groups, one way Analysis of Variance (ANOVA) was used. Scheffe Post Hoc test was also used to identify the location of significant differences among the different groups. The level of significance was $\mathrm{p}<0.05$.

Table 1. Mean \pm SD of age, height, weight, BMI, \% body fat, right hand grip, left hand grip of different groups

\begin{tabular}{|c|c|c|c|c|c|c|}
\hline Variable(s) & $\begin{array}{c}\text { Group 1 } \\
(n=30)\end{array}$ & $\begin{array}{c}\text { Group } 2 \\
(n=30)\end{array}$ & $\begin{array}{c}\text { Group 3 } \\
(n=30)\end{array}$ & $\begin{array}{c}\text { Group } 4 \\
(n=30)\end{array}$ & $\begin{array}{c}\text { Group } 5 \\
(n=30)\end{array}$ & $\begin{array}{c}\text { Total } \\
(n=150)\end{array}$ \\
\hline Age (year) & $\begin{array}{c}18.13 \pm 0 \\
77\end{array}$ & $\begin{array}{c}18.73 \pm 0.6 \\
9\end{array}$ & $18.53 \pm 0.68$ & $18.50 \pm 0.68$ & $18.67 \pm 0.47$ & $\begin{array}{c}18.51 \pm .0 .6 \\
5\end{array}$ \\
\hline Height (cm) & $\begin{array}{c}166.69 \pm . \\
2.62\end{array}$ & $\begin{array}{c}168.00 \pm .2 \\
62\end{array}$ & $\begin{array}{c}168.46 \pm .3 \\
24\end{array}$ & $\begin{array}{c}168.95 \pm .2 \\
79\end{array}$ & $\begin{array}{c}171.80 \pm 4.3 \\
7\end{array}$ & $\begin{array}{c}168.78 \pm .3 \\
12\end{array}$ \\
\hline Weight(kg) & $\begin{array}{c}51.50 \pm .1 \\
33\end{array}$ & $\begin{array}{c}55.70 \pm .1 .4 \\
1\end{array}$ & $61.50 \pm 0.88$ & $\begin{array}{c}66.33 \pm .1 .4 \\
0\end{array}$ & $74.25 \pm 3.22$ & $61.85 \pm 1.64$ \\
\hline BMI & $\begin{array}{c}18.54 \pm 0 \\
65\end{array}$ & $19.74 \pm .77$ & $21.69 \pm 0.90$ & $23.25 \pm 0.85$ & $25.18 \pm 1.43$ & $21.68 \pm 0.92$ \\
\hline \% Bodyfat & $\begin{array}{c}9.10 \pm 1.6 \\
7\end{array}$ & $\begin{array}{c}10.32 \pm 2.1 \\
3\end{array}$ & $11.92 \pm 1.43$ & $12.71 \pm 2.28$ & $14.88 \pm 3.06$ & $11.78 \pm 2.11$ \\
\hline $\begin{array}{l}\text { Right hand } \\
\text { grip (Kg) }\end{array}$ & $\begin{array}{c}43.13 \pm 6 \\
579\end{array}$ & $\begin{array}{c}44.16 \pm 4.8 \\
42\end{array}$ & $\begin{array}{c}45.53 \pm 2.81 \\
2\end{array}$ & $\begin{array}{c}49.73 \pm 6.75 \\
6\end{array}$ & $\begin{array}{c}56.50 \pm 5.67 \\
3\end{array}$ & $47.81 \pm 5.32$ \\
\hline $\begin{array}{l}\text { Left hand } \\
\text { grip (Kg) }\end{array}$ & $\begin{array}{c}39.36 \pm 6 \\
299\end{array}$ & $\begin{array}{c}41.30 \pm 6.0 \\
06\end{array}$ & $\begin{array}{c}43.60 \pm 3.95 \\
3\end{array}$ & $\begin{array}{c}47.26 \pm 6.90 \\
7\end{array}$ & $\begin{array}{c}53.83 \pm 6.30 \\
3\end{array}$ & $45.07 \pm 5.88$ \\
\hline
\end{tabular}




\section{Results}

Table 1 shows that the mean age of group1, group2, group3, group4 and group5 was $18.13 \pm .77$ year, $18.73 \pm .69$ year, $18.53 \pm .68$ year, $18.50 \pm .68$ year and $18.67 \pm .47$ year. The mean height of the subjects of group1, group2, group3, group4 and group5 was $166.69 \pm .2 .62 \mathrm{~cm}$ year, $168.00 \pm .2 .62 \mathrm{~cm}, 168.46 \pm .3 .24 \mathrm{~cm}, 168.95 \pm .2 .79 \mathrm{~cm}$ and $171.80 \pm 4.37 \mathrm{~cm}$. The mean weight of the subjects of group1, group2, group3, group4 and group5 was $51.50 \pm .1 .33 \mathrm{~kg}, 55.70 \pm .1 .41 \mathrm{~kg}, 61.50 \pm .88 \mathrm{~kg}, 66.33 \pm .1 .40 \mathrm{~kg}$ and $74.25 \pm 3.22 \mathrm{~kg}$. The mean body mass index of the subjects of group1, group2, group3, group4 and group5 was $18.54 \pm .65 \mathrm{Kg} / \mathrm{m}^{2}, \quad 19.74 \pm .77 \mathrm{Kg} / \mathrm{m}^{2}, \quad 21.69 \pm .90 \mathrm{Kg} / \mathrm{m}^{2}$, $23.25 \pm .85 \mathrm{Kg} / \mathrm{m}^{2}$ and $25.18 \pm 1.43 \mathrm{Kg} / \mathrm{m}^{2}$ respectively. The mean percent fat of the subjects of group1, group2, group3, group4 and group5 was $9.10 \pm 1.67 \%, 10.32 \pm 2.13 \%$, $11.92 \pm 1.43 \%, 12.71 \pm 2.28 \%$ and $14.88 \pm 3.06 \%$. The mean right hand grip of the subjects of group1, group2, group3, group4 and group5 was 43.133 $\pm 6.579,44.166 \pm 4.842$, $45.533 \pm 2.812,49.733 \pm 6.756$ and $56.500 \pm 5.673$. The mean left hand grip of the subjects of group1, group2, group3, group4 and group5 was 39.366 $\pm 6.299,41.300 \pm 6.006$, $43.600 \pm 3.953,47.266 \pm 6.907$ and $53.833 \pm 6.303$. Further, the analysis of variance (Table 2) revealed that the variance in the mean values of age, height, weight, BMI, \% body fat, right hand grip and left hand grip strength of junior free style wrestlers among different groups was statistical significant.

Table 2. Analysis of variance of age, height, weight, BMI, \% body fat, right and left hand grip strength among different groups

\begin{tabular}{lccccc}
\hline Variable(s) & Groups & Sum of Squares & Mean Square & F & Sig. \\
\hline Age & Between Groups & 6.50 & 1.627 & 3.63 & .008 \\
& Within Groups & 64.96 & .448 & & \\
\hline Height & Between Groups & 427.42 & 106.855 & 10.43 & .000 \\
& Within Groups & 1484.95 & 10.241 & & \\
\hline Weight & Between Groups & 9562.39 & 2390.600 & 706.97 & .000 \\
& Within Groups & 490.31 & 3.381 & & \\
\hline Body mass index & Between Groups & $\mathbf{8 4 9 . 9 4}$ & 212.485 & 230.09 & .000 \\
& Within Groups & 133.90 & .923 & & \\
\hline Percentage Fat & Between Groups & $\mathbf{5 9 4 . 5 7}$ & 148.644 & 30.86 & .000 \\
& Within Groups & 698.32 & 4.816 & & \\
\hline Right hand grip $(\mathrm{kg})$ & Between Groups & 3586.307 & $\mathbf{8 9 6 . 5 7 7}$ & 29.396 & .000 \\
& Within Groups & 4422.467 & 30.500 & & \\
\hline Left hand grip(kg) & Between Groups & 3915.693 & $\mathbf{9 7 8 . 9 2 3}$ & 27.368 & .000 \\
& Within Groups & $\mathbf{5 1 8 6 . 5 0 0}$ & 35.769 & & \\
\hline
\end{tabular}

*significant at the 0.05 level 
Table 3 shows a positive statistical significant relationship among percent body fat, height, and weight of combined $(\mathrm{N}=150)$ groups of junior free style wrestlers. A positive statistical significant relationship was also found between right and left hand grip strength and percent body fat, weight and BMI (Table 3).

Table 3. Correlation among age, height, weight, BMI, \% body fat, right hand grip, left hand grip variables of combined group $(\mathrm{N}=150)$

\begin{tabular}{|c|c|c|c|c|c|c|}
\hline Variable(s) & Height & weight & $\begin{array}{l}\text { Body } \\
\text { mass } \\
\text { index }\end{array}$ & $\begin{array}{l}\text { Percentage } \\
\text { fat }\end{array}$ & $\begin{array}{l}\text { Right } \\
\text { hand } \\
\text { grip }\end{array}$ & $\begin{array}{c}\text { Left } \\
\text { hand } \\
\text { grip }\end{array}$ \\
\hline Age & .076 & $.168^{*}$ & .160 & .080 & -.160 & -.122 \\
\hline Height & & $.483^{* *}$ & $.167^{*}$ & $.257^{* *}$ & $.188^{*}$ & .148 \\
\hline Weight & & & $.944^{* *}$ & $.722^{* *}$ & $.640^{* * *}$ & $.631^{* *}$ \\
\hline BMI & & & & $.717^{* *}$ & $.647^{* *}$ & $.654^{* *}$ \\
\hline $\begin{array}{l}\text { Percentage } \\
\text { fat }\end{array}$ & & & & & $.529^{* * *}$ & $.514^{* *}$ \\
\hline $\begin{array}{l}\text { Right } \\
\text { hand grip }\end{array}$ & & & & & & $.958^{* *}$ \\
\hline
\end{tabular}

\section{Discussion}

The results of the present study shows that the body fat percentage of the wrestlers of different groups were in the acceptable range according to the WHO (Laquatra, 2004). In other words, we can say no obesity was observed in different group of junior free style wrestlers. The maximum body fat percentage was observed in group 5 (higher weight category) and minimum in group1 (lower weight) wrestlers. Thus, a trend of increased in body fat percentage from lower body weight group $1(46 \mathrm{~kg}-50 \mathrm{~kg})$ to higher body weight group $5(74 \mathrm{~kg}$ ) of wrestlers was observed. The maximum lean body mass percentage was observed in group 1 and minimum lean body mass percentage was observed in group 5 . Thus, a trend of decrease in lean body mass percentage was observed from lower body weight group1 (46-50kg) to higher body weight group5 (74kg). Saygin (2014) also reported that the percentage body fat has different values in all three classes like lightweight, middle weight and heavy weight wrestlers. According to Saygin (2014) the maximum body fat was observed in heavyweight wrestlers when compared to lightweight wrestlers and middleweight wrestlers. Francihini et al. (2014) also reported that the highest skinfold thickness values were observed in heavyweight judo athletes as compared to lightweight and middleweight judo athletes, in other words, heavy weight judo athletes has more fat percentage than lightweight and middle weight. The mean value of various anthropometric variables body mass index was increased from lower 


\section{Journal of Exercise Science \& Physiotherapy, Vol. 12, No. 2, 2016 ISSN: 0973-2020 (Print) \\ ISSN: 2454-6089 (Online)}

body weight (group1) to higher body weight (group 5). Selda (2014) also reported that there was a significant difference in the body mass index of different weight categories of greco roman and free style wrestlers and the body mass index was higher in heavy weight greco roman and free style wrestlers as compared to the lower and middle weight greco roman and free style wrestlers. Selda (2014) reported that both heavy weight greco roman and free style group wrestlers was taller than the lower weight and middle weight wrestlers and a similar trend of body height was also found in the present study (i.e. junior free style wrestlers). The grip strength score of group5 wrestlers were more than the wrestlers of other groups. Further, the right hand grip strength score was more than left hand grip strength. Saygin (2014) showed that the hand grip strength were observed difference values in three weight classes of wrestlers in this study that values of hand grip strength were observed lower in the lightweight wrestlers when compared with the values of middleweight wrestlers and the values of heavyweight wrestlers. Right hand grip was observed stronger as compare to left hand grip. A significant difference was found in right handgrip and left hand grip strength among all groups of wrestlers $(p<0.05)$. Selda (2014) also reported that the heavy weight greco roman and the heavy weight freestyle wrestlers were found more strongest when compared with lower weight and the middle weight wrestlers.

\section{Conclusion}

From the results of the present study, it is concluded that the body fat percentage of the wrestlers of different groups was in the acceptable range i.e. obesity was not observed in them. Further, it is concluded that the wrestlers of lower body weight category (group1) were better in anthropometric variables than higher body weight category (group 5) like body fat percentage, body mass index. But (group5) were better in hand grip strength than lower body weight category (group 1) like right hand grip strength, left hand grip strength. A positive relationship was also observed between age, height, weight, BMI, \% body fat, right hand and left hand grip strength.

\section{References}

Durnin.JV. and Womersley J.(1974).Body fat assessed from total body density and its estimation from skinfold thickness: measurements on 481 males and females aged from 16 to 72 years. Br J Nutr, 32:77-97.

Franchini Emerson, Katarzyna Sterkowicz-Przybycien and Monica Yuri Takito. (2014).Anthropometrical Profile of Judo Athletes: Comparative Analysis between Weight Categories. Int. J. Morphol., 32(1):36-42.

Gallagher, E. C. (1951). Wrestling (Revised Edition ed.). New York: The Ronald Press Company.

Horswill C.A. (1992). Applied physiology of amateur wrestling.Sports Med 14:114-143.

Horswill C.A., Miller J.E., Scott J.R., Smith C.M., Welk G., Von Handel P.(1992). Anaerobic and aerobic power in arms and legs of elite senior wrestlers Int $\mathbf{J}$ Sports Med, 13, 558-561.

Horswill C.A., Scott J.R., Galea P.(1989). Comparison of maximum aerobic power, maximum anaerobic power, and skinfold thickness of elite and nonelite junior wrestlers.Int J Sports Med 10:165-168. 
HubnerWozniak E., Kosmol A., Lutoslawska G., Bem E.Z. (2004).Anaerobic performance of arms and legs in male and female free style wrestlers. J Sci Med Sport 7:473-480.

Kraemer W.J., Fry AC, Rubin M.R., Triplett-mcbride T., Gordon S.E., Koziris L.P., Lynch J.M., Volek J.S., Meuffels D.E., Newton R.U., Fleck S.J. (2001). Physiological and performance responses to tournament wrestling. Med Sci Sports Exerc 33:1367-1378.

Laquatra I. (2004). Nutrition for weight management. In Krause,,s Food, Nutrition, and Diet Therapy. Ed. by Mahan, L.K. and Escott-Stumps, S. 11th ed. Saunders Company, Philadelphia, Pennsylvanian, pp. 558-593.

Saygin O. (2014). Examination of Some Physical, Hematological Parameters and Iron Status of Greco-Roman Wrestlers in the Age Category of Cadets by Weight Classes Anthropologist 18(2): 325-334.

Selda Basara, IremDuzguna, Nevin Atalay Guzela, Ibrahim Cicioglub and Bulent Çelikc (2014) Differences in strength, flexibility and stability in freestyle and GrecoRoman wrestlers. Musculoskeletal Rehabilitation 27 321-330.

Sharratt M.T., Taylor A.W., Song T.M. (1986). A physiological profile of elite Canadian freestyle wrestlers. Can J Appl Sport Sci 11:100-105.

Steen, S. N., \& Brownell, K. D.(1990). Patterns of weight loss and regain in wrestlers: has the tradition changed. Med Sci Sports Exercise, 22(6), 762-768.

Yoon J. (2002). Physiological profiles of elite senior wrestlers. Sports Med 32:225-233.

Conflict of Interest: None Declared 